Gazi University
Journal of Science
PART A: ENGINEERING AND INNOVATION
http://dergipark.gov.tr/gujsa

\title{
Explanation of the Sutlegen Bauxites to Some REE Contents by Statistical Approach and Inequality Expressions
}

\author{
Ozge OZER ATAKOGLU1(D), Mustafa Gurhan YALCIN ${ }^{1 *(D)}$ \\ ${ }^{I}$ Department of Geological Engineering, Akdeniz University, 07058 Antalya, Turkey
}

\begin{tabular}{|c|c|}
\hline Keywords & Abstract \\
\hline $\begin{array}{l}\text { Statistical Analysis } \\
\text { Inequalities Expression }\end{array}$ & $\begin{array}{l}\text { Bauxite formation is usually possible in humid and tropical weather conditions with the enrichment of } \\
\text { minerals containing } \mathrm{Al}_{2} \mathrm{O}_{3} \text { in the environment. These minerals are found in chemical compositions that } \\
\text { are rich in major and trace elements, and REEs. Karst-type bauxites have different characteristics in } \\
\text { terms of REE and trace elements since they undergo alteration processes. Various correlations can be } \\
\text { evaluated using geostatistical methods to reveal the behavior of these elements in bauxitization } \\
\text { processes. The REE contents of the Sutlegen bauxite deposits were obtained by conducting ICP-MS } \\
\text { analysis. The inequality expressions of the La element, which is in the lanthanide group of the periodic } \\
\text { table and is included in the light rare earth elements, with Y element, the heavy and transition metal, has } \\
\text { provided information about the formation conditions of bauxite. The arithmetic mean of the La/Y ratios } \\
\text { of bauxites was found to be } 0.25 \text {, and the ore formation condition was interpreted as acidic. Therefore, } \\
\sum \mathrm{REE} \text { concentrations of the Sutlegen bauxite deposits were associated with } \sum \mathrm{LREE} / \mathrm{HREE} \text { and } \mathrm{La} / \mathrm{Y} \\
\text { ratios. } \sum \mathrm{REE} \text { concentration was found to be positively correlated with the } \sum \mathrm{LREE} / \mathrm{HREE} \text { and La/Y } \\
\text { ratios, and the correlation coefficients were found to be } 0.89 \text { and } 0.44 \text {, respectively. The positive } \\
\text { correlation between } \sum \mathrm{REE} \text { concentration and La/Y ratio can be interpreted that the pH in the bauxite } \\
\text { formation environment has a positive effect on REEs. Under the acidic conditions of ore formation, the } \\
\text { bauxites were enriched in REEs. }\end{array}$ \\
\hline
\end{tabular}

\begin{tabular}{lcc}
\hline Cite & \\
\hline Atakoglu, O. O., \& Yalcin, M. G. (2021). Explanation of the Sutlegen Bauxites to Some REE Contents by Statistical Approach and \\
Inequality Expressions. GU J Sci, Part A, 8(4), 391-401. & \\
\hline Author ID (ORCID Number) & Article Process \\
\hline O. Ozer Atakoglu, 0000-0003-2678-1194 & Submission Date & 25.08 .2021 \\
M. G. Yalcin, 0000-0002-8011-5371 & Revision Date & 29.09 .2021 \\
& Accepted Date & 05.10 .2021 \\
& Published Date & 06.10 .2021 \\
\hline
\end{tabular}

\section{INTRODUCTION}

In bauxite formation processes, the rare earth element (REE) concentrations, as well as the characteristics of the environment, vary due to chemical alteration processes (Maksimovic \& Panto, 1991; Yalcin \& Temur, 2006; Yalcin \& Ilhan, 2008; 2013; Kansun et al., 2010; Nyamsari \& Yalcin, 2017; Nyamsari et al., 2019; 2020; Sidibe \& Yalcin, 2019; Yalcin et al., 2012; 2016a). Rare earth elements are studied under two groups: light rare earth elements (LREEs) and heavy rare earth elements (HREEs). Bauxite formation depends on ambient conditions (Atakoglu \& Yalcin, 2021). For bauxite formation, the upper soil horizon is enriched with trace elements such as $\mathrm{Fe}$, Al. Acidic or alkaline conditions with $\mathrm{pH}$ varying between 4-5 are provided (Yang et al., 2019). With the effect of erosion, the chemical decomposition of the elements in the soil increases, trace and REE group elements decrease or increase, thus providing acidic or alkaline conditions. In order to understand these conditions that develop in the bauxite formation environment, the concentrations and ratios of some REE and trace elements should be looked at. The relationship of Y element, one of the transition metals, with lanthanides provides information about the $\mathrm{pH}$ conditions in the formation of bauxite (Maksimovic \& Panto, 1991). In bauxite formation processes, chemical decomposition reactions and the concentrations of REEs are affected by the other major and trace elements (Yalcin \& Ilhan, 2013; Yalcin et al., 2013; 2015; 2019a; 2020; 
Ozer \& Yalcin, 2019; 2020). Several studies in the literature on associating the behavior of REEs with the ore formation environment are as follows:

In the study conducted in four selected bauxite deposits in former Yugoslavia and Greece, the La, Y, and REE concentrations were determined by Maksimovic \& Panto (1991). The characteristics of the ore formation environment were revealed using the $\mathrm{La} / \mathrm{Y}$ ratios, and the findings were evaluated using the $\sum \mathrm{REE}$ concentrations. REE concentrations and the values of the elements of $\mathrm{Y}$ and La-Lu were analyzed for 4 different karstic bauxite deposits in former Yugoslavia and Greece. The formation patterns in bauxite deposits were suggested based on the values of the chemical concentrations (Maksimovic \& Panto, 1991).

In the study conducted on Henan Baofeng bauxite deposit in China, major elements, trace elements, and REE concentrations were analyzed. The value of $\mathrm{La} / \mathrm{Y}$ inequality was investigated to interpret the conditions of the ore formation environment. The rare earth element behavior of the ore, whose formation environment was interpreted, was associated with the value of La/Y inequality (Yang et al., 2019).

In the study on the Mandan and Deh-Now bauxite deposits, the REE concentrations were revealed and correlated with the $\mathrm{pH}$ conditions of the environment. According to the results of the study, the relationships between the major and trace elements and REEs that played a role in the formation were evaluated, and the sedimentary environment conditions were interpreted (Zarasvandi et al., 2012).

The study area covers the Sutlegen bauxite deposits in the Kas district of the province of Antalya. Interpretation of the origin and formation conditions is important for the bauxite raw material, which has economic value. Therefore, the formation conditions of bauxite were interpreted using the inequality expressions in the present study.

In the literature, no study was found on the interpretation of the ore deposit formation conditions using statistical approaches. In this context, the study was carried out for the statistical explanation of the correlation between the $\mathrm{La} / \mathrm{Y}$ ratios and REE concentrations of the bauxite deposits. Besides, the correlation between $\mathrm{pH}$ conditions and REE concentrations was also evaluated statistically in the study.

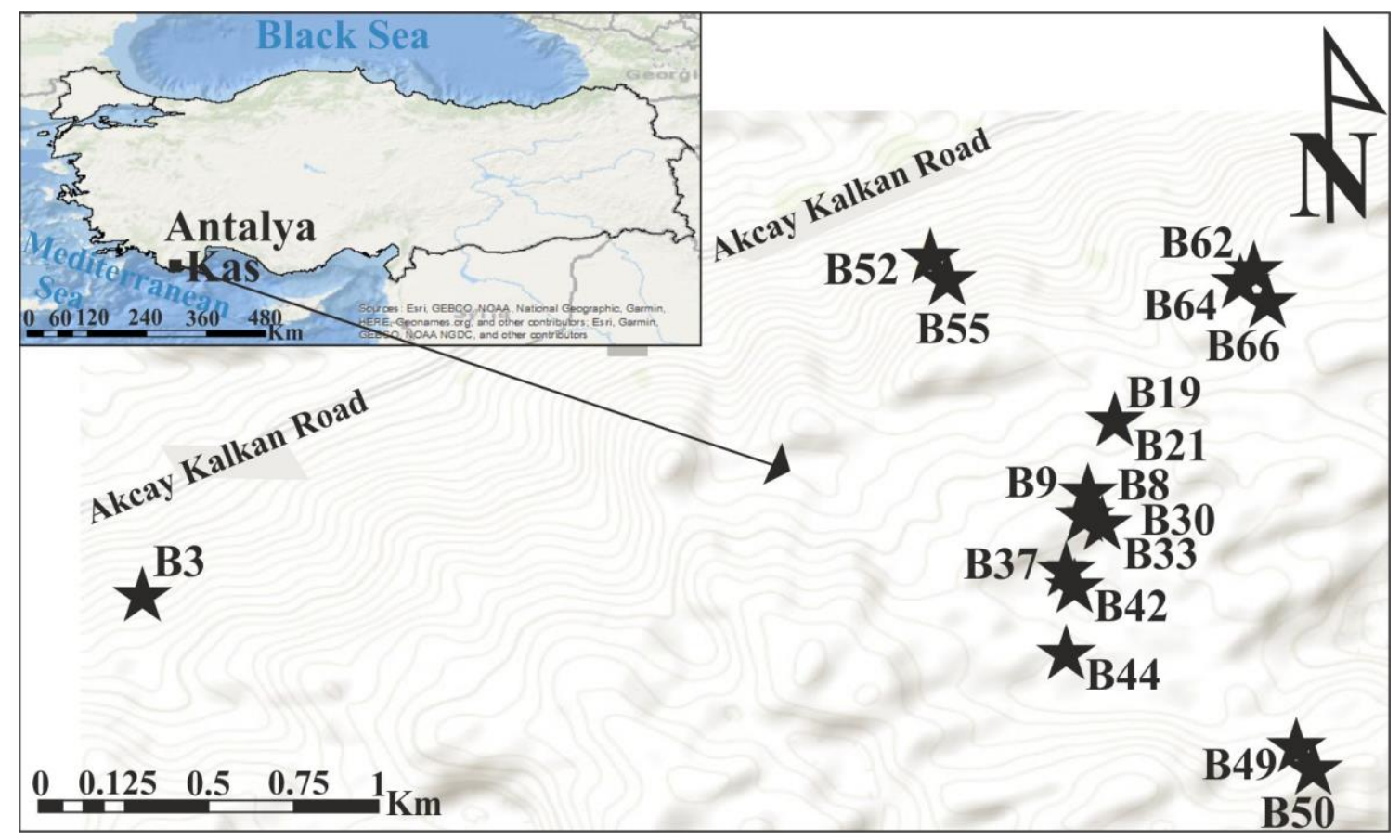

Figure 1. Site Location Map of the Study Area 


\section{MATERIAL AND METHOD}

Inductively Coupled Plasma Mass Spectrometry (ICP-MS) method was used to determine La, Y and REE concentrations of the Sutlegen bauxite deposits. Then, the statistical analysis of the findings of the ICP-MS method was conducted using the SPSS23 software package. The coordinate information of the samples collected from the Sutlegen was processed on the Turkey map using Arcmap 10.7 program and distribution maps were created.

\section{REGIONAL GEOLOGY}

The study area is located within the boundaries of Beydaglari carbonate rock association and Katran Mountain (Figure 2). Beydaglari autochthonous, which is composed of rocks showing angular unconformity, consists of neritic limestones and clastic units deposited in the Upper Cretaceous-Miocene age range (Keser \& Ozel, 2008). The units belonging to the Beydaglari autochthon on the exposed surfaces of the study area are listed as follows; Beydaglari formation consisting of Jurassic-Upper Cretaceous neritic limestones, Gomuce member which is Burdigalian aged algal unit, Caybogazi member as Burdigalian aged clayey unit, Kibrisdere member consisting of clayey limestones, Sinekci formation which is Burdigalian aged consisting of claystones, Kasaba formation which is Upper Burdigalian-Lower Langhian sandstone and conglomerate, Felenkdagi conglomerate which is Upper Langhian-Serravallian aged siltstone unit (Keser \& Ozel, 2008). Allochthonous units in tectonic relationship on Beydaglari are Elmali formation consisting of Upper Lutetian-Lower Burdigalian aged neritic limestones and Mandirkaya formation consisting of Liassic-Upper-Cretaceous clastic units. The youngest units in the region are represented by alluvium and slope debris (Keser \& Ozel, 2008) (Figure 3).

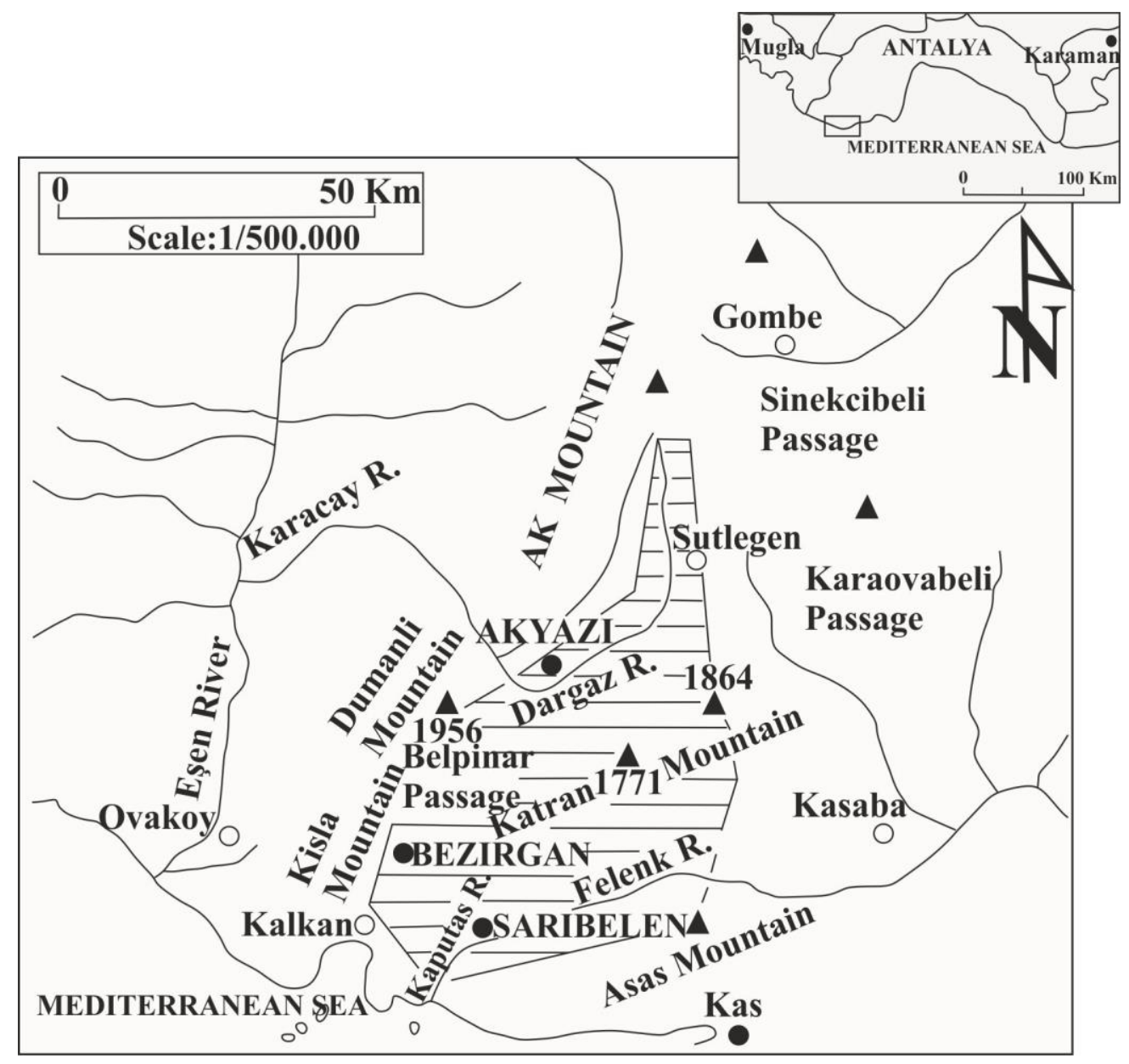

Figure 2. Boundaries Map of the Study Area (modified after Keser \& Ozel, 2008) 


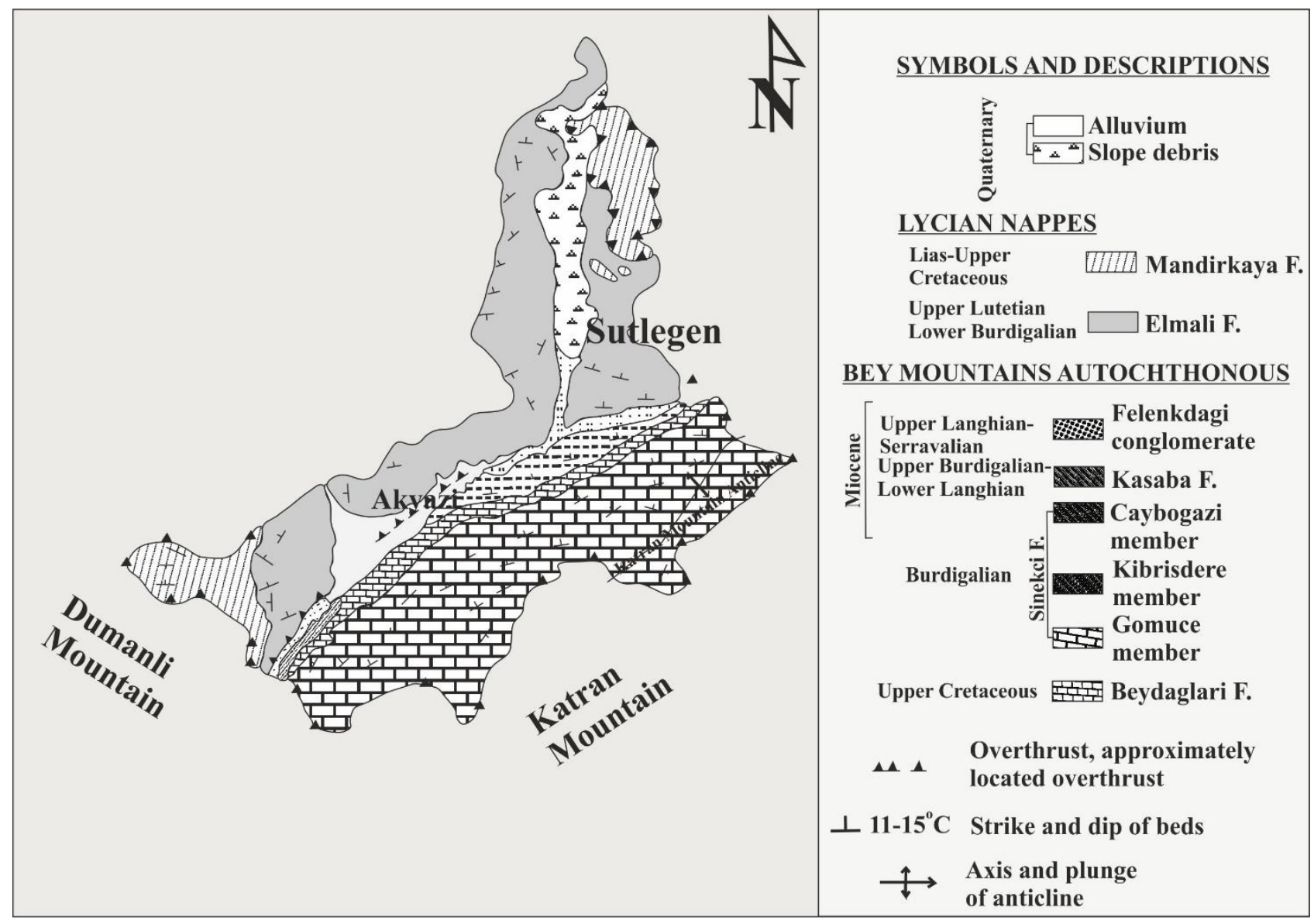

Figure 3. Regional Geologic Map of the Study Area (modified after Keser \& Ozel, 2008)

\section{RESULTS AND DISCUSSION}

REE element contents of 17 samples collected from the study area were revealed by conducting ICP-MS analysis (Table 1). The inequality expressions suggested for the La/Y concentrations by Maksimovic \& Panto (1991) and Zarasvandi et al. (2012) are as follows (1), (2):

$\mathrm{La} / \mathrm{Y}<$ Acidic conditions

$\mathrm{La} / \mathrm{Y}>$ Alkaline conditions

The findings were compared with the values of other karstic-type bauxite deposits in the literature. On the other hand, in the study conducted on the Henan karstic-type bauxite deposits in China, the bauxite formation condition was found to be generally alkaline (Yang et al., 2019). The La/Y ratio of the Grebnik karstic bauxite deposit was found to vary between 0.5 and 4 ; thus, it was interpreted that the transition from acidic to alkaline conditions could be possible by a carbonate contact (Maksimovic \& Panto, 1991). The box plot used for descriptive statistics is given in Figure 4.

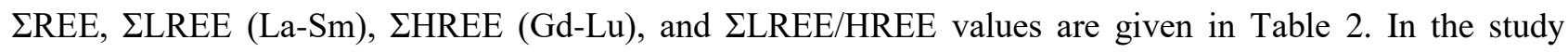
conducted on Baofeng bauxite deposits, the value of the coefficient of determination $\left(\mathrm{R}^{2}\right)$ of the model which was designed to explain $\sum$ REE using the $\sum$ LREE/ $\sum$ HREE ratio was found to be 0.57 . On the other hand, the $\mathrm{R}^{2}$ value of the model which was established to explain $\sum R E E$ using the $\mathrm{La} / \mathrm{Y}$ ratio was found to be 0.55 . The positive correlation found was associated with source rocks that played a role in the ore formation. It was interpreted that $\mathrm{pH}$ played a critical role in $\sum$ REEs, and it increased in total $\sum$ REE concentration under alkaline conditions (Yang et al., 2019). 
Table 1. REE Elements Results and La/Y Ratios of the Sutlegen Bauxites (ppm) (Ozer, 2020)

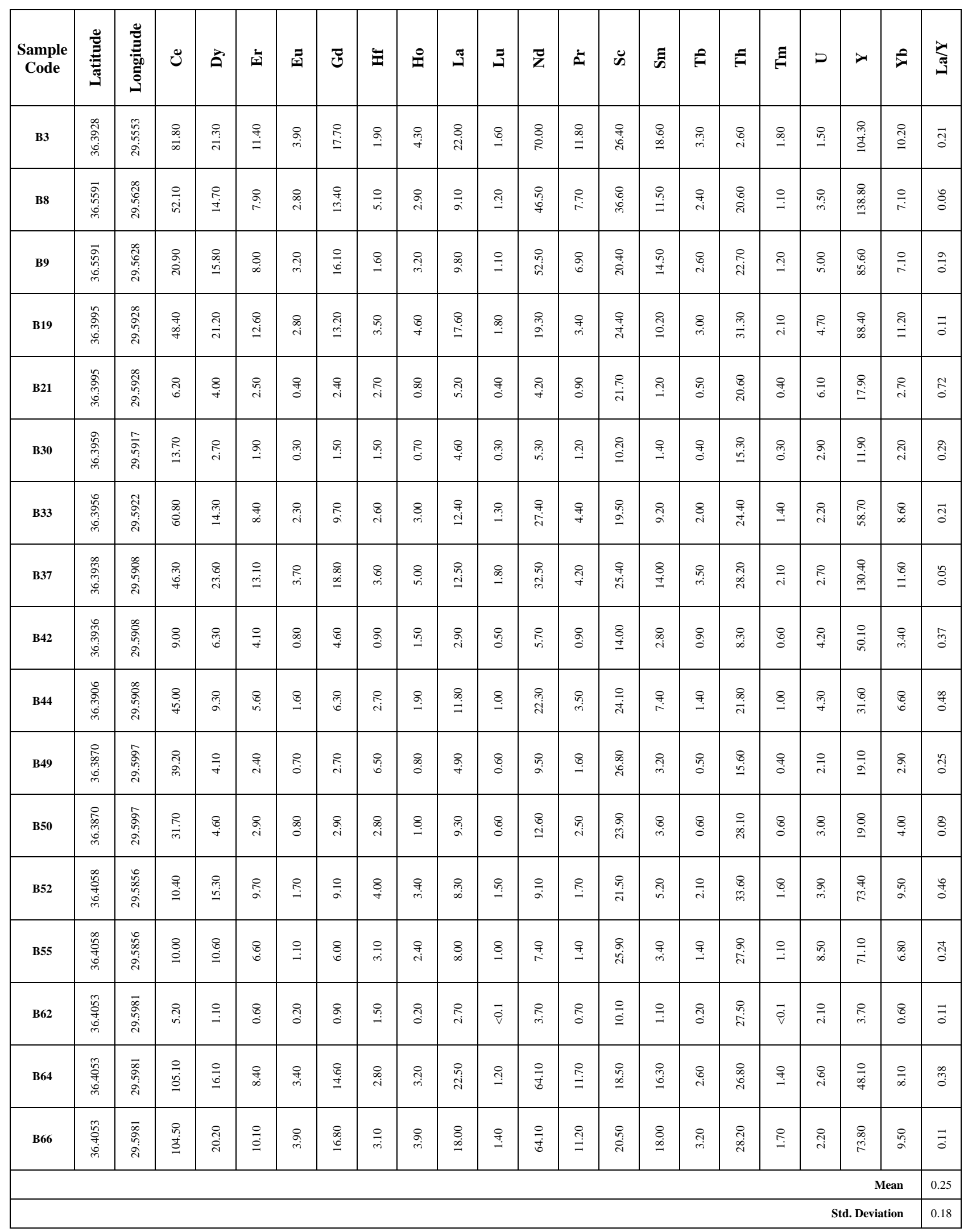



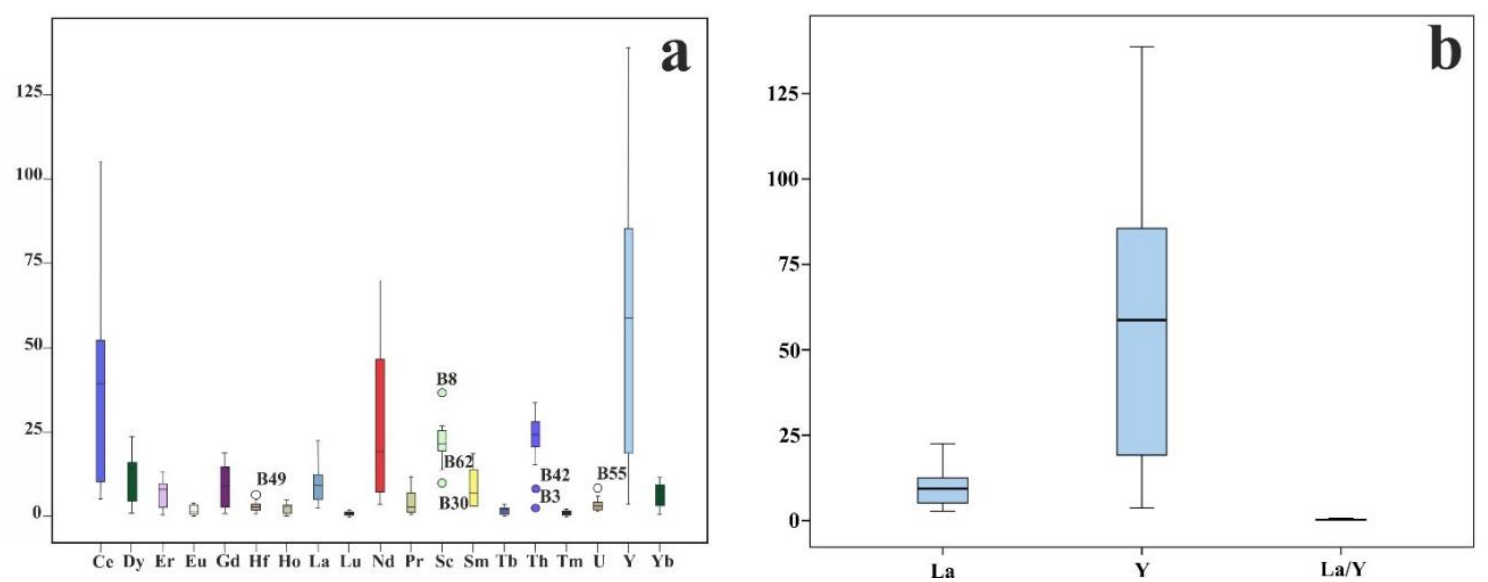

Figure 4. Box Plot of the a) REE of Bauxite Samples, b) La, Y and La/Y

As seen in Figure 5, the REE content was found to have a positive correlation with the $\sum$ LREE/HREE ratio, and the correlation coefficient was calculated as 0.89 . The $\sum$ REE behavior was observed to increase based on the $\sum$ LREE content. Furthermore, it was observed that the $\sum$ REE contents were positively correlated also with $\mathrm{La} / \mathrm{Y}$ ratios, and the coefficient of correlation was found to be 0.44 (Figure 6).

The explained variance (coefficient of correlation) $\left(\mathrm{R}^{2}\right)$ of the model that was designed to explain $\sum$ REE values using $\mathrm{La} / \mathrm{Y}$ and $\sum \mathrm{LREE} / \sum \mathrm{HREE}$ ratios was found to be 0.57 (Table 3). In other words, it is possible to explain about $57 \%$ of the variability of $\sum R E E$ with $\mathrm{La} / \mathrm{Y}$ and $\sum \mathrm{LREE} / \sum \mathrm{HREE}$ ratios. In addition, the error rate of this model was found to be 0 (Table 4). Therefore, explaining $\sum$ REE with $\mathrm{La} / \mathrm{Y}$ and $\sum \mathrm{LREE} / \sum \mathrm{HREE}$ ratios is statistically significant (Ozer \& Yalcin, 2019; 2020; Aydin et al., 2020; Ozer et al., 2020, Atakoglu et al., 2021; Ince et al., 2021; Yalcin et al., 2021).

Table 2. The Results of $\Sigma R E E$, $\Sigma L R E E$, $\angle H R E E$ and $\Sigma L R E E / \Sigma H R E E$ Calculations of the Bauxite Samples in the Study Area (Atakoglu \& Yalcin, 2021)

\begin{tabular}{|l|l|l|l|l|}
\hline Sample Code & $\sum$ REE & $\sum$ LREE & $\sum$ HREE & $\sum$ LREE/ HREE \\
\hline B3 & 295.9 & 185.6 & 103.4 & 1794.00 \\
\hline B8 & 209.9 & 115.4 & 93.6 & 12329.00 \\
\hline B19 & 184.6 & 88.7 & 101.6 & 0.87303 \\
\hline B55 & 86.3 & 44069 & 71.4 & 0.3753501 \\
\hline B62 & 44038 & 43902 & 16.00 & 0.76875 \\
\hline B21 & 50.8 & 43967 & 41.9 & 0.3937947 \\
\hline B33 & 176.1 & 105 & 72.7 & 14442916 \\
\hline B42 & 54.6 & 4396 & 40.9 & 0.4523227 \\
\hline B44 & 142.2 & 82.6 & 63.1 & 13090333 \\
\hline B50 & 97.6 & 56.1 & 44.9 & 12494432 \\
\hline B49 & 97.4 & 55.2 & 44 & 12545455 \\
\hline B37 & 206,00 & 95.5 & 111 & 0.85 \\
\hline B64 & 289.1 & 203.4 & 80.1 & 25393258 \\
\hline B66 & 297.5 & 197.8 & 93.4 & 2117773 \\
\hline B52 & 100.6 & 43980 & 79.3 & 0.372005 \\
\hline B30 & 44.5 & 440670 & 43944 & 10598291 \\
\hline B9 & 176.2 & 90.1 & 83.7 & 10764636 \\
\hline Mean & 14920 & 82576 & 685117 & 11277575 \\
\hline Std. Dvd. & 8981668 & 6347113 & 28885240 & 0.6123101 \\
\hline
\end{tabular}




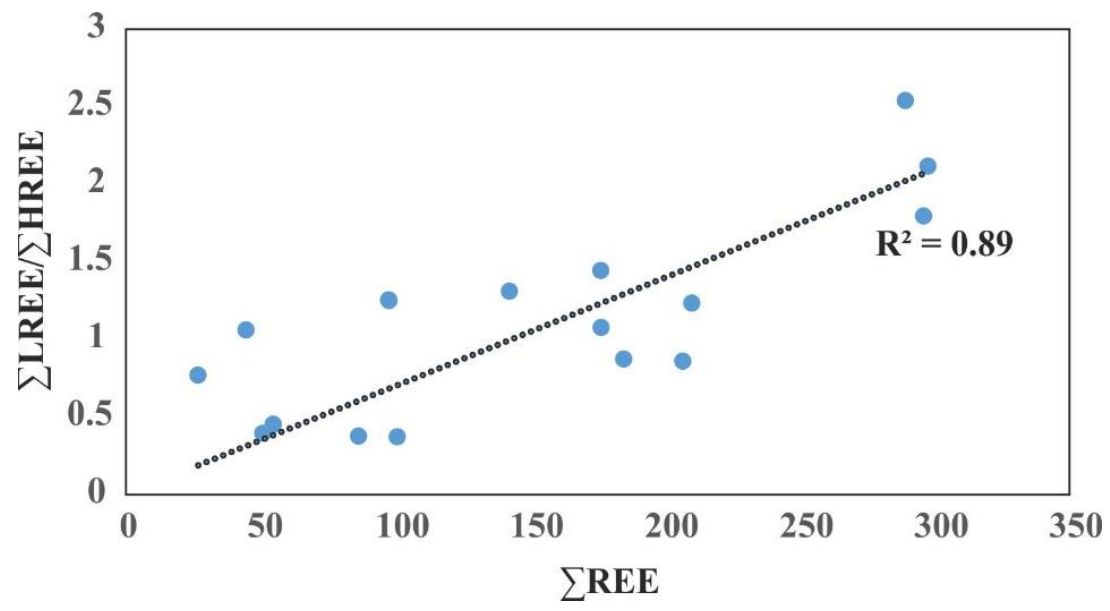

Figure 5. Simple Regression Scatter Diagrams of $\Sigma R E E$ versus $\Sigma L R E E / \Sigma H R E E$ Ratio

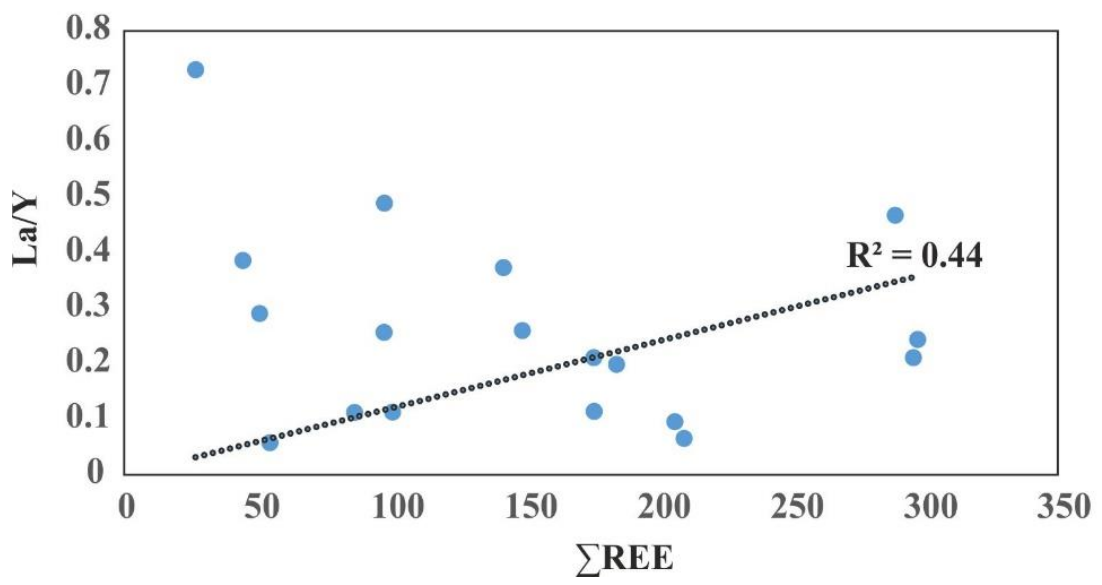

Figure 6. Simple Regression Scatter Diagrams of $\Sigma$ REE versus the La/Y Ratio

Table 3. Determination Coefficient of the Model Explaining $\Sigma R E E$ using the $\Sigma L R E E / \Sigma H R E E$ and La/Y Ratios

\begin{tabular}{|c|c|c|c|c|}
\hline \multicolumn{5}{|c|}{ Model Summary $^{\mathbf{b}}$} \\
\hline Model & $\mathrm{R}$ & R Square & Adjusted R Square & Std. Error of the Estimate \\
\hline 1 & $0.76^{2}$ & 0.57 & 0.51 & $\begin{array}{r}0.12 \\
\end{array}$ \\
\hline
\end{tabular}

Table 4. Error Data of the Model Explaining $\Sigma R E E$ using the $\Sigma L R E E / \Sigma H R E E$ and La/Y Ratios

\begin{tabular}{|c|c|c|c|c|c|c|}
\hline \multicolumn{7}{|c|}{ ANOVA $^{a}$} \\
\hline \multicolumn{2}{|c|}{ Model } & Sum of Squares & df & Mean Square & $\mathrm{F}$ & P-value \\
\hline \multirow[t]{3}{*}{1} & Regression & 0.30 & 2 & 0.15 & 0.63 & $\mathbf{0}^{\mathbf{b}}$ \\
\hline & Residual & 0.22 & 14 & 0.01 & & \\
\hline & Total & 0.52 & 16 & & & \\
\hline$b$ & $\begin{array}{l}\text { Dependent } \mathrm{V} \\
\text { redictors: }(\mathrm{C}\end{array}$ & $\begin{array}{l}\mathrm{La} / \mathrm{Y} \\
), \sum \mathrm{REE}, \sum \mathrm{LREE}\end{array}$ & & & & \\
\hline
\end{tabular}


The results of the correlation analysis performed according to $\mathrm{La}, \mathrm{Y}$ and $\mathrm{La} / \mathrm{Y}$ values are given in Table 5 . Factor analysis was performed to determine the variance ratios of $\mathrm{La}, \mathrm{Y}$ and $\mathrm{La} / \mathrm{Y}$ values and to understand the relationships they established (Yalcin \& Unal, 2018; Ozer et al., 2019; Tarinc et al., 2019a, b; Yalcin et al., 2007; 2008; 2019b; Yazici et al., 2021) (Table 6).

Table 5. Pearson's Correlation Coefficients Calculated using the Results of La, Y and La/Y

\begin{tabular}{|c|c|c|c|}
\hline & La & $\mathbf{Y}$ & La/Y \\
\hline $\mathbf{L a}$ & 1 & & \\
\hline $\mathbf{Y}$ & 0.463 & 1 & \\
\hline $\mathbf{L a} / \mathbf{Y}$ & -0.060 & $-0.719^{* *}$ & 1 \\
\hline
\end{tabular}

Table 6. Total Variance Explained According to Factor Analysis

\begin{tabular}{|c|c|c|c|c|c|c|}
\hline \multicolumn{7}{|c|}{ Total Variance Explained } \\
\hline \multirow{2}{*}{ Component } & \multicolumn{7}{|c|}{ Initial Eigenvalues } & \multicolumn{2}{c|}{ Extraction Sums of Squared Loadings } \\
\cline { 2 - 7 } & Total & \% of Variance & Cumulative \% & Total & \% of Variance & Cumulative \% \\
\hline $\mathbf{1}$ & $\mathbf{1 . 8 8}$ & 62.78 & 62.78 & 1.88 & 62.78 & $\mathbf{6 2 . 7 8}$ \\
\hline 2 & 0.94 & 31.51 & 94.29 & & & \\
\hline 3 & 0.17 & 5.70 & 100 & & & \\
\hline \multicolumn{7}{|c|}{ Extraction Method: Principal Component Analysis. } \\
\hline
\end{tabular}

The province polygon with the coordinates was selected and converted to raster data format in Arcmap 10.7 program. Distribution maps were created using the Krigging interpolation method with La, Y and the calculated $\mathrm{La} / \mathrm{Y}$ ratio values from REE group elements in raster data format (Yalcin et al., 2016b, c, d) (Figure 7).

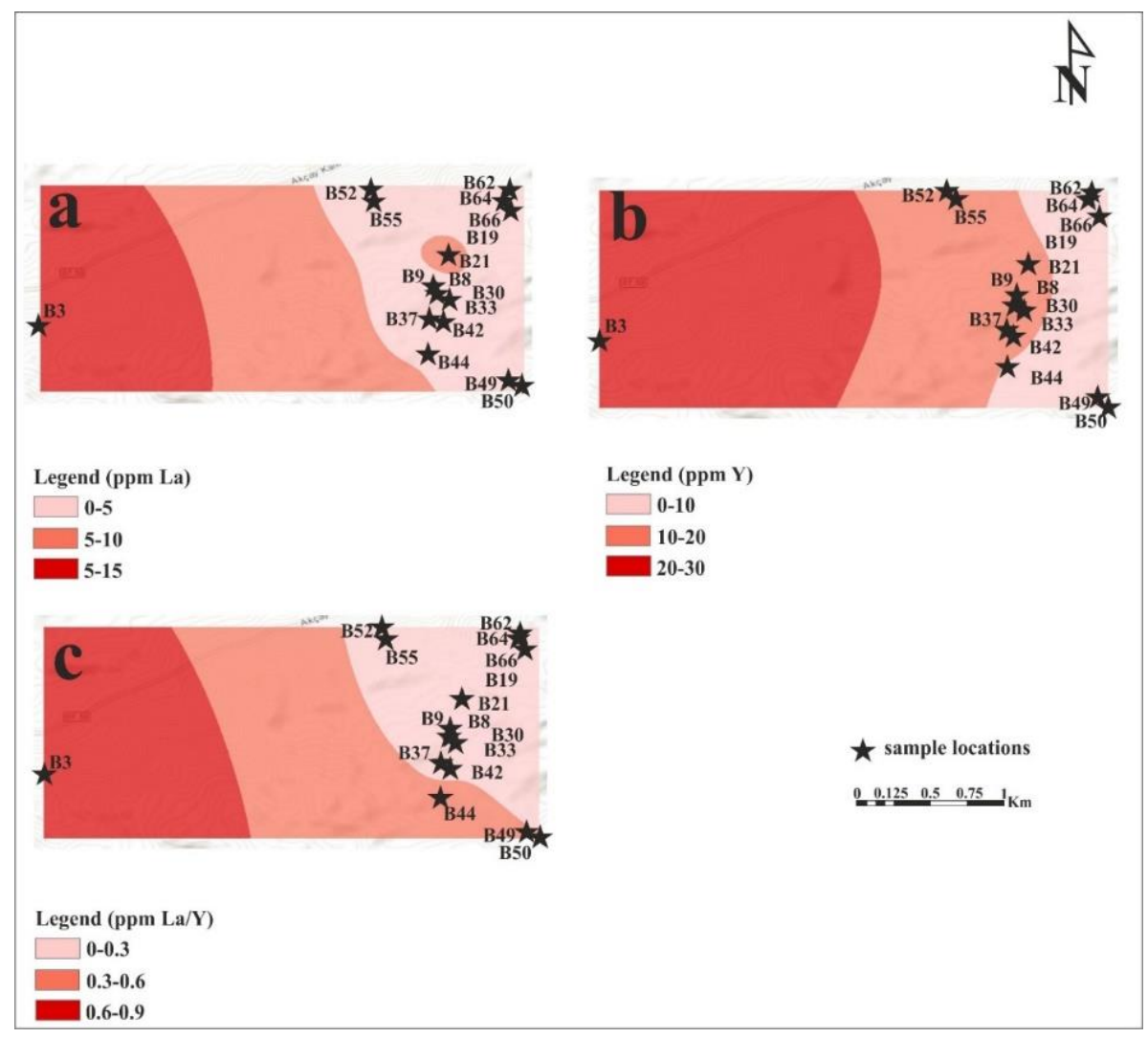

Figure 7. Spatial Distribution Maps of a) La, b) $Y$, c) La/Y 


\section{CONCLUSION}

In this study, the arithmetic mean of $\mathrm{La} / \mathrm{Y}$ ratios for the Sutlegen bauxites was calculated as 0.25 while the standard deviation was found to be 0.18 . It was interpreted that the formation conditions of bauxites were acidic. The positive correlation of $\mathrm{La} / \mathrm{Y}$ ratios, which were associated with the $\mathrm{pH}$ values of the ore formation environment, with $\sum$ REE provided the information that bauxites that were formed under acidic conditions were also enriched in REEs. The positive correlation of $\mathrm{La} / \mathrm{Y}$ ratios, which were associated with the $\mathrm{pH}$ values of the ore formation environment, with $\sum$ REE provided the information that bauxites that were formed under acidic conditions were also enriched in REEs. In the case of the Sutlegen bauxites, it was found that the $\sum$ REE concentrations increased under acidic conditions $(\mathrm{pH}<1)$, and the established model was statistically significant. According to the correlation analysis, there is a high-order negative-intermediate correlation between $\mathrm{Y}$ and $\mathrm{La} / \mathrm{Y}$. The data were collected under 1 factor with an eigenvalue greater than 1 , and it was seen that the 1 st factor explained $62.78 \%$ of the total variance.

The distribution maps obtained by the Krigging interpolation method; La and Y distributions of REE group elements are similar in the study area. The distribution of the $\mathrm{La} / \mathrm{Y}$ ratio calculated in this context is similar in the study area.

\section{ACKNOWLEDGEMENT}

This paper is a part of the M.Sc. thesis of Atakoglu Ozer O., the first author.

\section{CONFLICT OF INTEREST}

The authors declare no conflict of interest.

\section{REFERENCES}

Atakoglu, O. O., \& Yalcin, M. G. (2021). Geochemical characterization of the Sutlegen bauxite deposit, SW Antalya. Mining of Mineral Deposits, 15(3), 108-121. doi:10.33271/mining15.03.108

Atakoglu, O. O., Yalcin, M. G., \& Ozmen, S. F. (2021). Determination of radiological hazard parameters and radioactivity concentrations in bauxite samples: the case of the Sutlegen Mine Region (Antalya, Turkey). Journal of Radioanalytical and Nuclear Chemistry, 329(2), 701-715. doi:10.1007/s10967-021-07826-5

Aydin, B., Yalcin, F., Ozer, O., \& Yalcin, M. G. (2020). Regression analysis and statistical examiantion of knoop hardness on abrasion resistance in Lyca beige marbles. Filomat, 34(2), 609-614. doi:10.2298/FIL2002609A

Ince, Z., Atakoglu, O. O., \& Yalcin, M. G. (2021). Multivariate and spatial statistical analysis of geochemical data of dolomite: the case of industrial raw materials' differentiation. Montes Taurus J Pure Appl Math, 3(2), $8-28$.

Kansun, G., Yalcin, M. G., \& Copuroglu, I. (2010). Bolkardagi bauxite deposits at Ayranci, Karaman, central Turkey. Part 2. Mineralogical and petrographical studies. XIX Congress of the Carpathian-Balkan Geological Association Thessaloniki, Greece, 23-26 September, 39(1-2), 177.

Keser, N., \& Ozel, A. (2008). Three Examples to Explain the Formation and Development Mechanism of West Taurus Poljes. In: Natural Environment and Culture in Mediterranean Region, Cambridge Scholars Publishing, Part I, Chapter Fourteen, 197-214.

Maksimovic, Z., \& Panto, G. Y. (1991). Contribution to the geochemistry of the rare earth elements in the karst-bauxite deposits of Yugoslavia and Greece. Geoderma, 51(1-4), 93-109. doi:10.1016/00167061(91)90067-4

Nyamsari, D. G., \& Yalcin, M. G. (2017). Statistical analysis and source rock of the Minim-Martap plateau bauxite, Cameroon. Arabian Journal of Geosciences, 10(18), 415. doi:10.1007/s12517-017-3172-0 
Nyamsari, D. G., Yalcin, F., Mboh, M. T., Alfred, F. G., \& Yalcin, M. G. (2019). Natural radioactive risk assessment in topsoil and possible health effect in Minim and Martap villages, Cameroon: using radioactive risk index and statistical analysis. Kerntechnik, 84(2), 115-122. doi:10.3139/124.110927

Nyamsari, D. G., Yalçin, M. G., \& Wolfson, I. (2020). Alteration, Chemical Processes, and Parent Rocks of Haléo-Danielle Plateau Bauxite, Adamawa-Cameroon. Lithology and Mineral Resources, 55, 231-243. doi: $10.1134 /$ S0024490220030049

Ozer, O. (2020). The genesis and economic characteristics of the Sütleğen region (Kaş, Antalya) bauxite deposits. MSc Thesis, Akdeniz University, Antalya, 125 p. (Turkish).

Ozer, O., \& Yalcin, M. G. (2019). Modeling of elemental distribution of Kas (Antalya) bauxite deposit. In: II. International Conference of Numerical Analysis and Applied Mathematics (ICNAAM), Rhodes, Greece, 2328 September, 24-25.

Ozer, O., \& Yalcin, M. G. (2020). Correlation of chemical contents of Sutlegen (Antalya) bauxites and regression analysis. AIP Conference Proceedings, 2293(1), 180008. doi:10.1063/5.0026731

Ozer, O., Yalcin, F., Nyamsari, D. G., Yalcin, M. G. (2019). Appraisal of metal accumulation in beach sand using contamination indices and multivariate statistical analysis. In: Proceedings Book of the 2nd Mediterranean International Conference of Pure Applied Mathematics and Related Areas, Paris, France, 2831 August, 1-5.

Ozer, O., Yalcin, F., Tarinc, O. K., \& Yalcin, M. G. (2020). Investigation of suitability of marbles to standards with inequality expressions and statistical approach using some physical and mechanical properties. Journal of Inequalities and Applications, 97, 1-15. doi:10.1186/s13660-020-02360-6

Sidibe, M., \& Yalcin, M. G. (2019). Petrography, mineralogy, geochemistry and genesis of the Balaya bauxite deposits in Kindia region, Maritime Guinea, West Africa. Journal of African Earth Sciences, 149, 348-366. doi:10.1016/j.jafrearsci.2018.08.017

Tarinc, O. K., Ozer, O., Aydin, B., \& Yalcin, M. G. (2019a). Comparison of physical-mechanical properties of Clova and Lyca marbles in Akcay (Antalya) region by using independent-samples T-test statistics. In: Proceedings Book of the 2nd Mediterranean International Conference of Pure Applied Mathematics and Related Areas, Paris, France, 28-31 August.

Tarinc, O. K., Ozer, O., Yalcin, F., \& Yalcin, M. G. (2019b). Statistical evaluation of the chemical characteristics on marble in Akcay village (Elmali, Antalya) region. In: International Symposium on Advanced Engineering Technologies, Kahramanmaras, Turkey, 1333-1338.

Yalcin, M. G., \& Ilhan, S. (2008). Major and trace element geochemistry of Terra Rossa soil in the Kucukkoras region, Karaman, Turkey. Geochemistry International, 46(10), 1038-1054. doi:10.1134/S001670290810008X

Yalcin, M. G., \& Ilhan, S. (2013). Major and trace element geochemistry of bauxites of Ayranci, Karaman, central Bolkardag, Turkey. Asian Journal of Chemistry, 25(5), 2893-2904, doi:10.14233/ajchem.2013.14275

Yalcin, M. G., \& Temur, S. (2006). Geochemistry of the terra rossa from Ayranci, Central Turkey. Geochmica et Cosmochimica Acta, 70(18), doi:10.1016/j.gca.2006.06.1285

Yalcin, M. G., \& Unal, S. (2018). Natural radioactivity levels and associated radiation hazards in ophiolites around Tekirova, Kemer, and Kumluca Touristic Regions in Antalya, Turkey. Journal of Radioanalytical and Nuclear Chemistry, 316(1), 321-330. doi:10.1007/s10967-018-5760-1

Yalcin, M. G., Battaloglu, R., Ilhan, S., Tumuklu, A., \& Topuz, D. (2007). Heavy metal contamination along the Nigde-Adana highway, Turkey. Asian Journal of Chemistry, 19(2), 1506-1518.

Yalcin, M. G., Aydin, O., \& Elhatip, H. (2008). Heavy metal contents and the water quality of Karasu Creek in Nigde, Turkey. Environmental Monitoring and Assessment, 137, 169. doi:10.1007/s10661-007-9737-8

Yalcin, M. G., Karaman, M. E., \& Alagoz, Z. (2012). Origin of the red soils in the Bolkardag regıon: PinarkayaKayaonu case. (Karaman. Turkey). In: International Multidisciplinary Scientific GeoConference: SGEM: Surveying Geology Mining Ecology Management, 4, 149. 
Yalcin, M. G., Cevik, O., \& Karaman, M. E. (2013). Use of multivariate statistics methods to determine grain size, heavy metal distribution and origins of heavy metals in Mersin Bay (Eastern Mediterranean) coastal sediments. Asian Journal of Chemistry, 25(5), 2696-2702. doi:10.14233/ajchem.2013.13683

Yalcin, M. G., Setti, M., Karakaya, F., Sacchi, E., \& Ilbeyli, N. (2015). Geochemical and mineralogical characteristics of beach sediments along the coast between Alanya and Silifke (southern Turkey). Clay Minerals, 50(2), 233-248. doi:10.1180/claymin.2015.050.2.07

Yalcin, M. G., Nyamsari, D. G., Paksu, E., \& Yalcin, F. (2016a). Statistical assessment of rare earth elements of bauxite deposits of Minim-Martap Plateau. Cameroon. In: International Multidisciplinary Scientific GeoConference: SGEM: Surveying Geology Mining Ecology Management, 2, 819-825.

Yalcin, F., Kilic, S., Nyamsari, D. G., Yalcin, M. G., \& Kilic, M. (2016b). Principal component analysis of integrated metal concentrations of bogacayi riverbank sediments in Turkey. Polish Journal of Environmental Studies, 25(2), 471-485. doi:10.15244/pjoes/61009

Yalcin, M. G., Akturk, O., \& Paksu, E. (2016c). The contribution of west mediterranean cities (Antalya, Isparta and Burdur) to Turkey's natural stones-marble export. In: International Multidisciplinary Scientific GeoConference: SGEM: Surveying Geology \& Mining Ecology Management, 2, 875-880.

Yalcin, F., Nyamsari, D. G., Paksu, E., \& Yalcin, M. G. (2016d). Statistical assessment of heavy metal distribution and contamination of beach sands of Antalya-Turkey: an approach to the multivariate analysis techniques. Filomat, 30(4). 945-952. doi:10.2298/FIL1604945Y

Yalcin, M. G., Coskun, B., Nyamsari, D. G., \& Yalcin, F. (2019a). Geomedical, ecological risk, and statistical assessment of hazardous elements in shore sediments of the Iskenderun Gulf, Eastern Mediterranean, Turkey. Environmental Earth Sciences, 78(15), 438. doi:10.1007/s12665-019-8435-5

Yalcin, F., Ozer, O., Nyamsari, D. G., \& Yalcin, M. G. (2019b). Statistical evaluation of the geochemical content of beach sand along the Sarisu-Kemer coastline of Antalya, Turkey. AIP Conference Proceedings, 2116(1), 100005. doi:10.1063/1.5114081

Yalcin, F., Unal, S., Yalcin, M. G., Akturk, O., Ocak, S. B., \& Ozmen, S. F. (2020). Investigation of the Effect of Hydrothermal Waters on Radionuclide Activity Concentrations in Natural Marble with Multivariate Statistical Analysis. Symmetry, 12(8), 1219. doi:10.3390/sym12081219

Yalcin, M. G., Nyamsari, D. G., Atakoglu, O. O., \& Yalcin, F. (2021). Chemical and statistical characterization of beach sand sediments: implication for natural and anthropogenic origin and paleo-environment. International Journal of Environmental Science and Technology. doi:10.1007/s13762-021-03280-8

Yang, S., Wang, Q., Deng, J., Wang, Y., Kang, W., Liu, X., \& Li, Z. (2019). Genesis of karst bauxite-bearing sequences in Baofeng. Henan (China) and the distribution of critical metals. Ore Geology Reviews, 115, 103161. doi:10.1016/j.oregeorev.2019.103161

Yazici, I., Yalcin, M. G., Atakoglu, O. O., \& Yalcin, F. (2021) Multivariate Statistical Evaluation of Geochemical Properties of “Alanya Emperador Dark” Marbles. Gazi University Journal of Science Part A: Engineering and Innovation, 8(3), 361-372.

Zarasvandi, A., Carranza, E. J. M., \& Ellahi, S. S. (2012). Geological, geochemical, and mineralogical characteristics of the Mandan and Deh-now bauxite deposits, Zagros Fold Belt, Iran. Ore Geology Reviews, 48, 125-138. doi:10.1016/j.oregeorev.2012.02.010 